\title{
Papal confession: Darwin was right about evolution
}

Munich. Pope John Paul II has acknowledged the existence of evolution, nearly 150 years after Charles Darwin introduced the world to the idea that humans may not date back to God's seven days of creation.

In a statement last week to the Pontifical Academy of Sciences, an international body of about 80 prominent scientists, the Pope accepted that the overwhelming volume of experimental evidence in support of evolution could no longer be ignored. "Observational sciences describe and measure with ever increasing precision the multiple manifestations of life and inscribe them in an [evolutionary] timescale," he said.

Darwin had never been subject to the prolonged vilification that Galileo Galilei suffered from the Roman Catholic Church

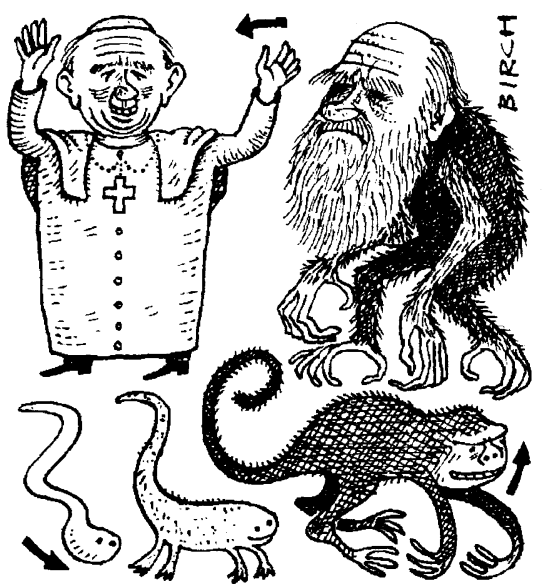

because of his rejection of Ptolemy in favour of Copernicus. Galileo was rehabilitated by John Paul II four years ago.

The strongest message from the Vatican on the theory of evolution had been in a encyclical letter issued by Pope Pius XII in 1950. The letter, called Humani Generis (Of the Human Species), warned of the threat Darwinism posed to central tenets of the Catholic faith. But it said that evolutionary theory was generally acceptable, provided that it was presented only as a hypothesis and not as a doctrine.

Pope John Paul II has now indicated that the Catholic Church is ready formally to accept scientific evidence that evolution is more than just a hypothesis - something that has been accepted in practice by most Catholic theologians for many years.

But, in his statement to the academy, the Pope drew a firm line between the material and the spiritual. He said that it is acceptable to believe that "the human body originates from living matter which predates it", but not that "the spirit is also a product of matter". The latter would lead to an unresolvable conflict between science and faith.

Alison Abbott

\section{Clinton woos women's votes with cancer genetics funds}

Washington. Ten days before next week's presidential election, in which the votes of women are expected to play a decisive role, President Bill Clinton announced last Sunday that he will redirect US\$30 million to breast cancer genetics research in 1997.

Exactly $\$ 20$ million will come from a $\$ 100$ million breast cancer research programme run by the US Army. That project has come under fire from some scientists, who claim it has ignored the scientific merits of grant proposals in pursuit of political ends (see Nature 383, 113; 1996). It will be instructed to devote \$20 million to breast cancer genetics grants "in collaboration with" the National Institutes of Health (NIH).

The president, whose mother died of breast cancer last year, made the announcement standing in the White House rose garden, surrounded by breast cancer survivors. He said the money will "support and expand breast cancer genetic research at hospitals, universities and laboratories across America". He called the step "a major increase in breast cancer genetic research".

The NIH spent about $\$ 60$ million on breast cancer genetics research in 1996, according to the office of director Harold Varmus. "What we're doing [with the new money] is putting greater emphasis on research on the genetics of breast cancer," says Anne Thomas, a spokeswoman for Varmus. "We want to take advantage of the progress that's been made in this area."

The new money has already been committed to biomedical research in the 1997 budget, which Clinton signed into law in September. It will be redirected within existing programmes. In addition to the money in the US Army programme, $\$ 10$ million will come from the NIH through the National Cancer Institute (NCI), the National Center for Human Genome Research, the National Institute of Environmental Health Sciences, Varmus's office, and elsewhere. Most of the money will be spent on investigator-initiated grants to study breast cancer genetics.

Reactions among breast cancer advocacy groups has been mixed. "We are always thrilled when there is an effort to recognize breast cancer as the significant disease to our society that it is," says Mary Jo Ellis Kahn of the National Breast Cancer Coalition. But she added that her group fears that the infusion of money might encourage women to rush out and seek testing for genetic predisposition to breast cancer - an area "fraught with incredible danger" to women because no comprehensive federal law bars employment and insurance discrimination based on the results of genetic tests.

Others charged the president with transparent politicking. Clinton's announcement, less than two weeks before voters decide on whether to grant him a second term, "illustrates the problems inherent in government funding scientific research", says Michael Tanner, a health policy analyst at the Cato Institute, a libertarian Washington think-tank.

The president has made a priority of appealing to women, a key swing-voting bloc, enacting laws ranging from unpaid family leave to longer hospital stays when women give birth.

The NIH expects to spend about $\$ 430$ million of its total budget of $\$ 12.7$ billion on breast cancer research in 1997.

Meredith Wadman

\section{BSE link prompts German vote on sheep}

London. The German cabinet is to vote next week on a proposal from its federal health ministry to ban the importation from Britain and France of certain sheep parts - in particular brains, spinal cords and eyeballs - out of concern that they could have become infected with bovine spongiform encephalopathy (BSE).

The decision comes soon after last week's announcement of the first scientific evidence, produced by a team headed by John Collinge of Imperial College Medical School in London, of a direct link between BSE and a new strain of Creutzfeldt-Jakob disease (CJD) in humans (see Nature 383, 685-690; 1996).

Speaking at a press conference in London last week, Collinge said that one of the possible applications of his discovery of biochemical evidence linking the two diseases directly was that it might also be used to look for the emergence of BSE in other animals.

In particular, it was now possible, at least in theory, to distinguish sheep that could have been infected with BSE from those suffering from one of the many different strains of scrapie, another prion disease which is thought by some to be at the origin of BSE itself. "It is possible that BSE may have gone back into sheep," says Collinge.

British officials point out that it has been compulsory to destroy the heads of both sheep and goats at the point of slaughter as a precautionary measure since last summer. The main issue of contention at present is whether the spinal cord should be left in carcasses that are exported. 